\title{
Perbandingan Pendidikan; Pemahaman Simbolis dan Substantif PAI di Madrasah dan Sekolah
}

\author{
Moh. Wardi \\ STAI Nazhatut Thullab Sampang \\ Email: mohwardi84@gmail.com \\ Ismail \\ STAI Nazhatut Thullab Sampang \\ Email: yajlisismail@gmail.com \\ Ali Makki \\ STIS AS-Salafiyah Sumber Duko Pamekasan \\ Email: alimakkimusaffak@gmail.com
}

\begin{abstract}
Madrasah and schools have the same vision, mission and goals, namely the organizers of education in order to educate the life of the nation. Both of these institutions each have their own uniqueness and characteristics, because of their different backegrounds and histories. Competition and competition between educational institutions are still finding things that are unfair and cause polemics with each other. Even though the status and pos of the madrasa is the same as the school as the Joint Decree of the Minister of Religion of the Republic of Indonesia, the Minister of Home Affairs of the Republic of Indonesia, and the Minister of Education and Culture, and SKB 3 Minister Number 06/1975.037/U/1975, and Number 36/1975 about improving the quality and quality of education in madrasas. The main points and substance of the referred SKB are first, that the recognition of diplomas at madrasah graduates can have a value equivalent to the recognition of public school diplomas and equivalent. Secondly, graduates / madrasah alumni can continue their studies to public schools and those who are on a higher level. And third, students in the madrasa can transfer to public schools of the same level. If we understand the difference between madrasa and school, it is only limited to textual understanding, it will lead us to a simple understanding and be trapped in mere symbolic understanding. So when these differences can be created at school, the difference between madrasa and other schools will disappear.
\end{abstract}

\section{Keywords : Comparative of Islamic Education, Madrasah and Schools}

Terdapat kesamaan visi, misi serta tujuan Madrasah dan sekolah yaitu penyelenggara pendidikan dalam rangka mencerdaskan kehidupan bangsa. Kedua lembaga ini masingmasing memiliki keunikan dan ciri khas tersendiri, karena latar belakang dan sejarahnya yang berbeda pula. Persaingan dan kompetisi antar lembaga pendidikan masih saja ditemukan halhal yang tidak fair dan menimbulkan polemik satu sama lainnya. Padahal status dan kedudukan madrasah sama dengan sekolah sebagaimana Surat Keputusan Bersama Menteri Agama RI, Menteri Dalam Negeri RI, dan Menteri Pendidikan dan Kebudayaan RI, dan (SKB 3 Menteri) Nomor 06/1975,037/U/1975, dan Nomor 36/1975 tentang peningkatan

Nidhomul Haq: Jurnal Manajemen Pendidikan Islam

ISSN: 2503-1481 Hal: 23-33

DOI: $10.31538 /$ ndh.v4i1.104 
mutu dan kualitas pendidikan pada madrasah. Hal pokok dan substansi dari SKB dimaksud adalah Pertama, bahwa pengakuan terhadap ijazah pada lulusan madrasah dapat mempunyai nilai yang setara dengan pengakuan ijazah sekolah umum dan yang sederajat. Kedua, lulusan/alumni madrasah dapat melanjutkan studi lanjut ke sekolah umum dan yang setingkat lebih atas. Dan Ketiga, siswa pada madrasah dapat mutasi ke sekolah umum yang setingkat/sederajat. Apabila kita memahami perbedaan antara madrasah dan sekolah hanya terbatas pada pemahaman tekstual saja, maka akan membawa kita pada pemahaman yang sederhana dan terjebak pada pemahaman simbolis semata. Sehingga ketika perbedaanperbedaan tersebut mampu di ciptakan di sekolah, maka perbedaan antara madrasah dan sekolah lembat laun akan menjadi sirna.

Kata kunci: Perbandingan Pendidikan Islam, Madrasah dan Sekolah

\section{A. PENDAHULUAN}

Dalam konteks

ke-Indonesiaan, pemerintah memberikan ruang dan kesempatan untuk memilih dan menempuh pendidikan sesuai dengan minat dan selera masing-masing warganya untuk memilih lembaga pendidikan. Bagi mereka yang berkeinginan mendominasi pendidikan umum, maka memilih jalur pendidikan umum, jikalau ingin mendominasi pendidikan agama, bisa memilih lembaga pendidikan pesantren, dan bagi yang berkeinginan kedua-duanya keseimbangan antara agama dan umum bisa mengambil jalur madrasah.

Madrasah dan sekolah mempunyai visimisi dan tujuan sama yaitu mencerdaskan kehidupan bangsa, Ditengah-tengah perbedaan dan kesamaan dari lembaga pendidikan yang dimaksud, tidak jarang kita jumpai persaingan dan kompetisi, kita temukan kompetisi antar lembaga pendidikan yang ada sering tidak fair dan menimbulkan disharmoni satu lembaga dengan lembaga lainnya.

Bentuk kompetisi ketidak-fair-an antar lembaga pendidikan diantaranya berupa stigma negatif dari sebagian masyarakat, bahwa madrasah merupakan refresentasi lembaga pendidikan yang kolot, kumuh, ndeso, tidak maju. Tentunya hal ini menimbulkan dampak negatif dalam keberlangsungan dan eksistensi madrasah, banyak masyarakat dan orang tua yang kemudian ragu menempatkan anakanaknya menuntut ilmu di madrasah, faktanya adalah bahwa stigma-stigma negatif yang bermunculan di masyarakat tidaklah semuanya benar dan dapat dijadikan refresentasi dari sekian banyak madrasah itu sendiri. Kalapun ada, hal itu hanyalah segelintir dari sekian banyak Pondok Pesantren yang didalamnya menaungi madrasah yang ada di Indonesia.

Sementara stigma negatif yang muncul pada instansi Sekolah bahwa sekolah 
merupakan pencetak kader kapitalis, yang sederajat. Kedua, lulusan/alumni madrasah mementingkan kehidupan duniawi, sekuler. dapat melanjutkan studi lanjut ke sekolah Dari sekian banyak stigma negatif yang umum dan yang setingkat lebih atas. Dan bermunculan di masyarakat, adalah menjadi Ketiga, siswa pada madrasah dapat mutasi ke tantangan dan tugas para pendidik termasuk pemerintah untuk memberikan pemahaman dan wawasan kepada masyarakat bahwa agama tidak pernah membeda-bedakan ilmu pengetahuan harmoni Madrasah dan sekolah.

Dalam perjalanan sejarahnya masa awal Orde Baru, sekitar tahun 1967 sampai dengan tahun 1970, dilakukan alih status konversi dari swasta ke negeri, serta menrubah nama dan struktur Madrasah Negeri di lingkungan Madrasah Tsanawiyah MTs dan Madrasah Aliyah MA Selanjutnya, tahun 1975, melalui SKB 3 Menteri, madrasah ditingkatkan mutu pendidikannya. ${ }^{1}$

Berangkat dari SKB 3 Menteri tersebut, PAI di madrasah menjadi sejajar dengan sekolah umum. Surat Keputusan Bersama Menteri Agama RI, Menteri Dalam Negeri RI, dan Menteri Pendidikan dan Kebudayaan RI, dan $\quad$ SKB 3 Menteri Nomor 06/1975,037/U/1975, dan Nomor 36/1975 tentang peningkatan mutu dan kualitas pendidikan pada madrasah. Hal pokok dan substansi dari SKB dimaksud adalah Pertama, bahwa pengakuan terhadap ijazah pada lulusan madrasah dapat mempunyai nilai yang setara dengan pengakuan ijazah sekolah umum dan

1 Keputusan Bersama Menteri Agama, Menteri Pendidikan dan Kebudayaan, dan Menteri Dalam Negeri (SKB 3 Menteri) No.06/1975,037/U/1975, dan 36/1975 tentang peningkatan mutu pendidikan pada madrasah. sekolah umum yang setingkat/sederajat. ${ }^{2}$

Implikasi dari SKB 3 Menteri ini adalah bahwa seluruh madrasah harus merevisi kurikulum, yakni $70 \%$ memuat ilmu pengetahuan umum dan $30 \%$ ilmu pengetahuan memuat ilmu agama. Dengan mi pula diharapkan LPI dapat meningkatkan kualitasnya sehingga mampu berkompetisi dengan sekolah umum, dan proporsi dan Jam Tatap Muka JTM materi pelajaran agama Islam PAI. $^{3}$

Atas dasar pemikiran inilah maka penulis mencoba berikhtiar untuk memahami dan memberikan pencerahan terkait PAI di Madrasah dan PAI di Sekolah dalam tinjauan historis, filosofis, dan sosiologis guna memahami fungsi, peran dan perbedaan diantara kedua lembaga tersebut.

\section{B. KAJIAN TEORI}

Istilah Madrasab dalam bahasa Arab adalah bentuk kata keterangan lokasi zharaf makan dari asal usul kata darasa. Secara harfiah madrasah diartikan sebagai wahama dan lokasi belajar para pelajar. Dalam versi bahasa Indonesia, madrasah memiliki arti sekolah. Pemahaman madrasah tidak berbeda dengan

\footnotetext{
2 Mahmud Arif, Panorama Pendidikan Islam di Indonesia, (Yogyakarta, Idea Press, 2009), hlm. 69

3 M. Irsyad Djuwaeni, Pembaruan Kembali Pendidikan Islam, (Jakarta: Karsa Utama Mandiri, 1998), hlm. 53.
} 
sekolah, namun di Indonesia madrasah tidak lantas dipahami sebagai sekolah, melainkan lebih spesifik lagi, yakni identik dengan sekolah agama, tempat di mana anak-anak didik memperoleh pembelajaran keagamaan Islam. ${ }^{4}$

Madrasah mengandung arti sebagai lembaga formal dan proses pembelajaran dan pendidikannya menitikberatkan pada persoalan ajaran agama. Seiring dengan perjalanan peradaban bangsa meteri pelajaran yang diberikan kepada anak peserta didiknya, madrasah mulai menambah forsi mata pelajaran umum dengan tidak melepaskan diri dari makna asalnya yakni budaya dan tradisi Islam. $^{5}$

Madrasah merupakan perluasan dan pengembangan pendidikan dari pondok pesantren yang mempunyai misi untuk mencerdaskan anak bangsa yang pada saat itu belum ada keinginan untuk tinggal atau menginap di pondok dalam proses belajarnya siswa Kalongan. Diawali di Kota Padang oleh Syekh Amrullah Ahmad 1907, KH. Ahmad Dahlan 1912 di Yogyakarta, KH Wahab Hasbullah bersama KH Mansyur 1914 dan KH. Hasyim asy'ari yang pada tahun 1919 mendirikan Madrasah Salafiyah di Tebuireng Jombang. ${ }^{6}$ Instutisi ini memang lahir sekitar awal abad $20 \mathrm{M}$, periode ini dikenal dengan

\footnotetext{
4 A. Malik Fadjar, Madrasah dan Tantangan

Modernitas, (Mizan: Bandung, 1999), hal. 18

5 Ibid, Hal, 19

6 Abdul Rachman Saleh, Pendidikan Agama dan Keagamaan Visi, Misi dan Aksi, Jakarta: PT. Gemawindu Pancaperkasa, 2000), hlm, 112.
}

istilah pertumbuhan madrasah dalam sejarah pendidikan Islam di Indonesia. ${ }^{7}$

Lahirnya madrasah sebagai salah satu bentuk pembaruan pendidikan Islam di Indonesia. Alasannya adalah secara historis sebagai respon pendidikan Islam terhadap kebijakan pendidikan Hindia Belanda. Selain itu, munculnya madrasah sebagai usaha untuk pembaruan dan menjembatani antara sistem tradisional pesantren dengan sistem pendidikan modern. Sebagai upaya penyempurnaan terhadap sistem pendidikan di pondok pesantren kearah suatu sistem pendidikan yang lebih memungkinkan lulusannya memperoleh kesempatan yang sama dengan sekolah umum. Menampung keinginan dari para santri yang tidak hanya ingin mengaji semata namun juga ingin sekolah pada lembaga pendidikan formal yang kemudian pada akhirnya mendapatkan ijazah. Banyaknya madrasah yang bermunculan pada lingkungan pondok pesantren ini, kemudian oleh Mukti Ali sering disebut dengan Madrasah dalam Pesantren. ${ }^{8}$

Kemudian dalam perkembanganya model madrasah sering di istilahkan sebagai Madrasah Berbasis Pesantren.' Maraknya madrasah, menurut Steenbrink tidak serta merta kemudian menghilangkan tradisi pesantren yang sudah bertahan lama, tradisi

\footnotetext{
7 Maksum, Madrasab: Sejarah dan Perkembangannya, (Jakarta: Logos Wacana Ilmu, 1999), Hlm, 98.

8 A. Mukti Ali, Metode Memahami Agama Islam, (Jakarta: Bulan Bintang, 1991), hlm. 11-12.

9 Mahmud Arif, Panorama Pendidikan Islam di Indonesia....... Hlm, 89.
} 
keagamaan, tradisi intelektual dan tradisi mempunyai nilai yang setara dengan kepemimpinan khas pesantren masih banyak di pengakuan ijazah sekolah umum dan yang temukan pada madrasah yang berada di sederajat. Kedua, lulusan/alumni madrasah lingkungan pesantren. ${ }^{10}$

Kemunculan madrasah sebagai indikator penting bagi perkembangan budaya umat Islam, mengingat realitas pendidikan, keunggulan capaian keilmuan, intelektual dan kultural timbul kebanggaan terhadap madrasah, karena lembaga ini mempunyai citra eksklusif dalam penilaian masyarakat luas. Karena dalam catatan sejarah, madarasah pernah menjadi lembaga pendidikan par excellence di dunia Islam, hal ini terjadi karena kedudukannya yang sedemikian prestisius di mata umat Islam. Melalui lembaga ini, dinamika intelektualkeagamaan mencapai puncaknya.

Dalam tinjauan sosiohistoris, dalam rangka memajukan dan peningkatan mutu pendidikan madrasah dan mengembangkan sistem pendidikan nasional yang integral, keMenterian Agama yang saat itu dijabat olehC. HASIL DAN PEMBAHASAN

Mukti Ali pada tahun 1975 mengeluarkan Surat Sosiohistoris Dan Eksistensi PAI di Keputusan Bersama Menteri Agama RI, Menteri Dalam Negeri RI, dan Menteri

\section{Sekolah}

Dalam membahas akar munculnya Pendidikan dan Kebudayaan RI, dan SKB 3 sekolah di Indonesia, hal ini sebaiknya kita Menteri Nomor 06/1975.037/U/1975, dan melihat perjalanan sejarah dan pola Nomor 36/1975 tentang peningkatan mutu kolonialisme belanda yang terjadi sekitar 350 dan kualitas pendidikan pada madrasah. Hal tahun menerapkan sistem feodalisme dan pokok dan substansi dari SKB dimaksud kolonialisme di negeri ini. Ketika Belanda adalah Pertama, bahwa pengakuan terhadap mulai menjajah Nusantara Indonesia dengan ijazah pada lulusan madrasah dapat bentuk penjajahan dengan mengambil semua SDA, kekayaan dan rempah-rempah pada

${ }^{10}$ Karel A. Steenbrink, Pesantren Madrasah Sekolah, Pendidika Islam dalam Kurun Modern, (Jakarta : LP3ES, 1994), Hlm. 220.

11 Mahmud Arif, Panorama Pendidikan..... Hlm, 69 
sebagian besar wilayah Indonesia, Belanda pun mulai melakukan penjajahan jenis baru terhadap dunia pendidikan yang sabelumnya warga pribumi melakukan kegiatan pendidikan di masjid dan pondok pesantren. Penjajahan model baru yang dilakukan dengan membentuk lembaga pendidikan baru yang dinamakan Sekolah. ${ }^{12}$

Dalam catatan sejarah, tanggal 8 Maret 1819, Gubernur Belanda yang ditugaskan mengawasi Indonesia dengan nama lengkapnya Jenderal Vander Capellen mengintruksikan kepada anak buahnya untuk mengadakan penelitian tentang pendidikan masyarakat jawa, guna meningkatkan kemampuan membaca dan menulis di kalangan mereka. Dengan hasil penelitain tersebut diharapkan pelaksanaan undang-undang dan peraturan pendidikan dapat diperbaiki. ${ }^{13}$

Eksistensi PAI di sekolah umum bersifat fluktuatif menurut kebijakan pemerintah yang ada saat itu. Pada masa Belanda, sekolah umum tidak diperbolehkan memasukkan agama Islam sebagai kurikulum mata pelajaran, dengan alasan netralitas kurikulum dan pengajaran di sekolah umum. Pelajaran agama hanya diperkenankan diluar kegiatan berbentuk ekstra kurikuler, kondisi ini berlangsung sampai berakhirnya pemerintahan Belanda. Pada masa pendudukan Jepang terjadi regulasi kebijakan

12 Jaih Mubarok, Sejarah Peradaban Islam,

(Bandung: CV Pustaka Islamika, 2008), Hkm, 254.

${ }^{13}$ Karel A. Steenbrink, Pesantren Madrasah Sekolah, Pendidikan Islam dalam Kurun Modern, (Jakarta: LP3ES, 1994), Hlm..1 dalam bidang pendidikan, Jepang membolehkan pendidikan agama menjadi kurikulum di sekolah umum meskipun guru agama tidak mendapatkan gaji oleh pemerintah.

Setelah Indonesia merdeka, dinyatakan dengan tegas bahwa pendidikan agama perlu dijalankan di sekolah-sekolah Negeri. Hasil kerja Panitia Penyelidik Pengajaran memutuskan bahwa pelajaran agama diberikan pada semua sekolah dalam jam pelajaran, sedangkan di SR Sekolah Rakyat, sekarang Sekolah Dasar diajarkan mulai kelas IV. Guru agama disediakan oleh Kementerian Agama dan dibayar oleh pemerintah, dengan ketentuan bahwa guru agama harus mempunyai pengetahuan umum.

Kemudian, cara menyelenggarakan pengajaran agama di sekolah Negeri diatur melalui SKB dua menteri sebagai penjelasan atas UUPP No.4 Tahun 1950, di antaranya jumlah jam pelajaran ditetapkan dalam undangundang tentang jenis Sekolahnya dan bahwa pendidikan agama tidak mempengaruhi kenaikan kelas anak. Di samping itu, keputusan ini memuat ketentuan tentang lamanya pendidikan agama dalam seminggu 2 jam pelajaran tiap minggu, masalah pengangkatan dan pembiayaan guru agama, kewajiban guru agama, rencana pelajaran agama, petunjuk bagi guru agama, dan pendidikan agama di sekolah partikelir. 
Keputusan memberikan pelajaran agama di sekolah mulai kelas IV ini berkembang terus dan mengalami serangkaian perubahan kebijakan. Pada tahun 1960 dinyatakan bahwa pendidikan agama menjadi kurikulum mata pelajaran di sekolah-sekolah mulai jenjang SD sampai dengan Universitas Negeri, dengan beberapa pertimbangan bahwa murid-murid berhak tidak ikut serta apabila wali/murid menyatakan keberatan dalam proses KBM, lalu pada tahun 1966 kebijakan tersebut dihapus dengan menyatakan bahwa pendidikan agama menjadi pelajaran yang wajib diberikan di seluruh jenjang pendidikan negeri/swasta, mulai dan SD sampai dengan Universitas Negeri. ${ }^{14}$

Tahun-tahun berikutnya, searah dengan kebijakan pemerintah Orde Baru, pengembangan sekolah diarahkan pada penambahan fisik dan non fisik berupa pengadaan sarana dan prasarana bidang keagamaan karena pendidikan agama merupakan bagian dan pembentukan manusia seutuhnya. Hingga UUSPN No. 2 Tahun 1989 diberlakukan, pengadaan dan peningkatan sarana dan prasarana terus dilakukan, meskipun karena problem sosial-ekonomi jumlahnya naikturun, tetap bisa disepakati bahwa animo masyarakat untuk sekolah kian meningkat.

\footnotetext{
${ }^{14}$ Abdurrahman Assegaf, Internasionalisasi Pendidikan; Sketsa Perbandingan Pendidikan di NegaraNegara Islam dan Barat, (Yogyakarta: Gama Media, 2003), Hlm, 294.
}

Kini, tidak mengherankan bila jumlah sekolah, siswa, dan guru sejak kemerdekaan hingga sekarang terus melaju dengan perkembangan jumlah lembaga yang terus meningkat. Disebutkan bahwa yang termasuk dalam jenis peningkatan sarana pendidikan itu meliputi: sarana fisik bangunan sekolah, perabot, dan peralatan kantor, media pendidikan perangkat keras ataupun peranqkat lunak, alat peraga dan praktik, serta perbukuan sekolah.

Dalam perkembangannya saat ini, sebagaimana diatur dalam UU Nomor 20 Tahun 2003 tentang SISDIKNAS, sekolah dapat di kelompokkan menjadi tiga. Ditinjau dari segi yang mengusahakan, tingkatan dan ditinjau dari segi sifatnya. ${ }^{15}$

\begin{tabular}{|l|l|l|l|}
\hline \multirow{2}{*}{ No } & \multicolumn{3}{|c|}{ KLASIFIKASI SEKOLAH } \\
\cline { 2 - 4 } & $\begin{array}{c}\text { Tingkat } \\
\text { /Jenjang }\end{array}$ & $\begin{array}{l}\text { Penyeleng } \\
\text { gara }\end{array}$ & Sifat \\
\hline 1. & $\begin{array}{l}\text { Pendidikan } \\
\text { Dasar } \\
\text { SD/MI } \\
\text { SMP/MTs }\end{array}$ & $\begin{array}{l}\text { Sekolah } \\
\text { Negeri }\end{array}$ & $\begin{array}{l}\text { Sekolah } \\
\text { umum }\end{array}$ \\
\hline 2. & $\begin{array}{l}\text { Pendidikan } \\
\text { Menengah } \\
\text { SMA/MA } \\
\text { SMK/MAK }\end{array}$ & Sekolah & Sekolah \\
Swasta & kejuruan \\
\hline 3. & Pendidikan & & \\
\hline
\end{tabular}

${ }^{15}$ Hasbullah, Dasar-dasar Ilmu Pendidikan, (Jakarta: Rajawali Pers, 2009), Hlm. 52 


\begin{tabular}{|l|l|l|l|}
\hline Tinggi & \\
Akademi & & \\
Politeknik & & & \\
Tinggi & Institut & & \\
Universitas & & \\
& & & \\
\end{tabular}

\section{Pemahaman Simbolis Antara Madrasah Dan Sekolah}

Perbedaan yang sangat prinsip antara Madrasah dan sekolah adalah, bahwa Madrasah adalah sekolah umum yang memiliki ciri khas Agama Islam. Sementara Sekolah tidaklah demikian. Para kaum simbolis mengatakan bahwa perbedaan antara Madrasah dan sekolah dapat dilihat dalam tabel berikut:

\begin{tabular}{|c|c|c|}
\hline \multirow{2}{*}{ No } & \multicolumn{2}{|c|}{ PEMAHAMAN SIMBOLIS } \\
\hline & PAI Madrasah & PAI Sekolah \\
\hline 1. & $\begin{array}{lr}\text { Mata } & \text { pelajaran } \\
\text { agama } & \text { terbagi } \\
\text { kedalam } & \text { submata } \\
\text { pelajaran } & \text { Fiqh, dll }\end{array}$ & $\begin{array}{l}\text { Mata pelajaran } \\
\text { Pendidikan } \\
\text { Agama Islam } \\
\text { digabung } \\
\text { menjadi satu }\end{array}$ \\
\hline 2 & $\begin{array}{l}\text { Alokasi waktu } \\
\text { pelajaran agama } \\
\text { relatif lama. } \\
\text { Masing-masing sub } \\
\text { mata pelajaran } 2 \\
\text { Jam Tatap Muka } \\
\text { perminggu. }\end{array}$ & $\begin{array}{lr}\text { Alokasi } & \text { waktu } \\
\text { pelajaran } & \text { agama } \\
\text { relatif } & \text { singkat } \\
\text { karena menjadi 2 } & \\
\text { Dua Jam } & \text { Tatap } \\
\text { Muka } & \text { JTM } \\
\text { perminggu }\end{array}$ \\
\hline
\end{tabular}

\begin{tabular}{|c|l|lr|}
\hline 3 & $\begin{array}{l}\text { Tradisi salam ketika } \\
\text { berjumpa dewan } \\
\text { guru dengan ucapan } \\
\text { Assalamu'alaikum } \\
\text { Wr. Wb. }\end{array}$ & $\begin{array}{l}\text { Tradisi lebih } \\
\text { bervariasi dengan } \\
\text { ucapan selamat } \\
\text { pagi dst }\end{array}$ \\
\hline 4 & $\begin{array}{l}\text { Kegiatan belajar } \\
\text { mengajarnya di } \\
\text { dahului dengan do'a } \\
\text { baik opening dan } \\
\text { closing }\end{array}$ & $\begin{array}{l}\text { Sebagian besar } \\
\text { tidak demikian, } \\
\text { karena gurunya } \\
\text { latarbelakang } \\
\text { pendidiknnya }\end{array}$ \\
\hline
\end{tabular}

\section{Pemahaman Substantif Antara Madrasah dan Sekolah}

Dapat dipahami bahwa, manakala kita memahami perbedaan antara madrasah dan sekolah hanya sebagaimana tersebut diatas maka akan membawa kita pada pemahaman yang sederhana dan terjebak pada pemahaman simbolis semata. Sehingga ketika perbedaan perbedaan tersebut mampu di ciptakan di sekolah, maka perbedaan antara madrasah dan sekolah lembat laun akan menjadi sirna.

Sementara untuk membedakan pendidikan Islam yang kemudian bahasa penulis disebut dengan istilah madrasah, maka dominasi muatan kurikulum pendidikan agama islam alokasi waktunya lebih lama sehingga ciri khas dan karakter yang sudah menjadi tradisi di madrasah sulit di seragamkan dengan sekolah.

Diantara karakteristik pendidikan Islam/ Madrasah yang kemudian bisa dipahami sebagai pemahaman substantif antara 
Madrasah dan Sekolah antara lain adalah: Pertama, Madrasah sebagai bagian dari Pendidikan Islam yang bercorak Islami bisa dilihat dari kurikulumnya yang lebih banyak muatan keagamaan, karena memang tujuan berdirinya untuk menanamkan nilai-nilai agama. ${ }^{16}$ Bahkan madrasah yang ada dibawah naungan pondok pesantren salaf, sangat minim memberikan mapel pendidikan umum. ${ }^{17}$

Kedua, kaderisasi ulama ${ }^{18}$ lembaga yang melahirkan SDM yang handal dengan sejumlah penilaian yang mulia seperti: ikhlas, mandiri, penuh dengan perjuangan dan tabah serta telah teruji oleh perkembangan zaman.

Ketiga, Madrasah senantiasa menjadi tempat pemeliharaan Tradisi dan budaya Islam. ${ }^{19}$ Arus globalisasi menjadi tantangan yang dapat meruntuhkan pendidikan Islam. Ciri khas pendidikan Islam menjadi sirna dirampas oleh arus perkembangan zaman yang sulit dikontrol oleh lembaga dan individu muslim. Namun karena komitmen dan integritas yang kuat, madrasah tetap mampu

16 Azyumardi Azra, Pendidikan Islam, Tradisi dan Modernisasi Menuju Milenium Baru (Jakarta: Logos Wacana Ilmu, 1999), 10.

17 Sampai saat ini masih ada pondok pesantren yang tetap tegar berdiri diatas ideology sufistik sebagai paradigma kependidikannya. Misalnya, pesantren Karay Ganding Sumenep dan Pondok Pesantren al-Is'af Klabaan Guluk-Guluk SumenepMadura. Lihat. Imam Tholkhah dan Ahmad Barizi, Membuka Jendela Pendidikan, Mengurai Akar Tradisi dan Integrasi Keilmuan Pendidikan Islam (Jakarta: PT. Raja Grafindo Persada), 58.

18 Malik Fajar, Visi Pembaharuan Pendidikan Islam (Jakarta Pusat: CV. Alfa Grafikatama, 1998), 124.

19 Azyumardi Azra, Esai-Esai Intelektual Muslim dan Pendidikan Islam (Jakarta: Logos Wacana ilmu, 1999), 89. memposisikan dirinya sebagai pemelihara tradisi Islam.

Keempat, Penanaman nilai-nilai fondasi keilmuan bukan pengembangan. ${ }^{20}$ Sejak dini ilmu agama telah ditanamkan dalam diri batin peserta didik, menguatkan keyakinan mereka melalui iman dan taqwa. Al-hasil, output dari lembaga madrasah, setelah mengabdikan diri ke masyarakat tetap tampil eksis dengan mempertahankan ilmu yang telah didapat. Keempat, aktualisasi dan legitimasi seseorang untuk berkembang memiliki prinsip kepribadian yang kokoh. ${ }^{21}$

Kelima, Aktualisasi ilmu dan pengetahuan atas dasar tanggung jawab kepada Tuhan Hablun min Allab dan manusia/masyarakat Hablun min An-nas. ${ }^{22}$ Disini pengetahuan bukan untuk diketahui dan dikembangkan, melainkan sekaligus dipraktekkan dalam kehidupan nyata di masyarakat. Di dalam Islam, mengetahui suatu ilmu pengetahuan sama urgensinya dengan pengamalannya secara nyata dalam wujud keimanan dan ketakwaan. ${ }^{23}$

Predikat dan penilaian seperti inilah yang sulit dimiliki oleh peserta didik. Orang yang bagus didepan manusia belum tentu bagus didepan Allah, begitupun sebaliknya. Karena itu, semua dihadapan Allah derajat manusia adalah sama, hanya yang membedakan terletak pada tingkat ketaqwaan dan

\footnotetext{
${ }^{20}$ Ibid, 89.

21 Azyumardi Azra, Pendidikan Islam, Tradisi dan Modernisasi, 10

22 Ibid, 10.

${ }^{23}$ Mastuhu, Memberdayakan Sistem Pendidikan Islam (Jakarta: Logos Wacana Ilmu, 1999), 20.
} 
keimanannya semata. Untuk menumbuhkan keimanan dan ketaqwaan, dibutuhkanE. REFERENSI pengetahuan agama yang utuh, dan untuk mendapatkan ilmu agama yang komprehensif salah satu jalan yang harus ditempuh adalah belajar di lembaga pendidikan Islam Madrasah.

\section{KESIMPULAN}

Tantangan dan tugas para pendidik, orang tua, masyarakat dan pemerintah adalah memberikan pemahaman dan pencerahan bahwa agama tidak ada dikotomi dalam ilmu pengetahuan agama dan umum. sehingga kemudian dapat meminimalisir keengganan masyarakat untuk memilih lembaga pendidikan tempat anak-anaknya Madrasah atau sekolah.

Pemahaman lain terhadap masyarakat, bahwa janganlah terjebak pada pemahaman dan makna simbolis saja, namun pemahaman yang bersifat substantif dan kontekstual menjadi tujuan dan akhir dari segalanya. Apabila kita memahami perbedaan antara madrasah dan sekolah hanya terbatas pada pemahaman tekstual saja, maka akan membawa kita pada pemahaman yang sederhana dan terjebak pada pemahaman simbolis semata. Sehingga ketika perbedaanperbedaan tersebut mampu di ciptakan di sekolah, maka perbedaan antara madrasah dan sekolah lembat laun akan menjadi sirna.
Ali, Mukti, Metode Memahami Agama Islam, Jakarta: Bulan Bintang, 1991.

Arif, Mahmud, Panorama Pendidikan Islam di Indonesia, Yogyakarta, Idea Press, 2009.

Assegaf, Abdurrahman, Internasionalisasi Pendidikan; Sketsa Perbandingan Pendidikan di Negara-Negara Islam dan Barat, Yogyakarta: Gama Media, 2003.

Azra, Azyumardi, Pendidikan Islam, Tradisi dan Modernisasi Menuju Milenium Baru Jakarta: Logos Wacana Ilmu, 1999.

Azra, Azyumardi, Esai-Esai Intelektual Muslim dan Pendidikan Islam Jakarta: Logos Wacana ilmu, 1999.

Djuwaeni, M. Irsyad, Pembaruan Kembali Pendidikan Islam, Jakarta: Karsa Utama Mandiri, 1998.

Fadjar, A. Malik, Madrasah dan Tantangan Modernitas, Mizan: Bandung, 1999. , Visi Pembaharuan Pendidikan Islam Jakarta Pusat: CV. Alfa Grafikatama, 1998.

Hasbullah, Dasar-dasar Ilmu Pendidikan, Jakarta: Rajawali Pers, 2009.

Maksum, Madrasah: Sejarah dan Perkembangannya, Jakarta: Logos Wacana Ilmu, 1999.

Mastuhu, Memberdayakan Sistem Pendidikan Islam Jakarta: Logos Wacana Ilmu, 1999.

Mubarok, Jaih, Sejarah Peradaban Islam, Bandung: CV Pustaka Islamika, 2008. 
Nidhomul Haq, Vol 4 No 1 Tahun 2019

Saleh, Abdul Rachman, Pendidikan Agama dan Keagamaan Visi, Misi dan Aksi, Jakarta: PT. Gemawindu Pancaperkasa, 2000.

Steenbrink, Karel A. Pesantren Madrasah Sekolah, Pendidika Islam dalam Kurun Modern, Jakarta: LP3ES, 1994.

Tholkhah, Imam, dan Ahmad Barizi, Membuka Jendela Pendidikan, Mengurai Akar Tradisi dan Integrasi Keilmuan Pendidikan Islam Jakarta: PT. Raja Grafindo Persada. 